\title{
Raktamokshana - A Systemic Review
}

\author{
Review Article
}

\section{Gaurav Sawarkar*1, Punam Sawarkar², Priti Desai ${ }^{3}$}

1. Associate Professor, Department of Rachana Shareer,

2. Associate Professor, Department of Panchakarma,

3. Professor, Department of Rachana Shareer,

Mahatma Gandhi Ayurved College Hospital and Research Centre, Salod (H),

Datta Meghe Institute of Medical Sciences (Deemed to be University), Wardha, Maharashtra, India.

\begin{abstract}
Raktamokshana is the important para surgical method of bloodletting incorporated by Acharya Sushruta in the basic plan of detoxification therapy. Though the broad utility of this therapy is extensively elaborated in Ancient Text of Ayurveda, it has limited use in the clinical practices of Panchakarma that may occur due to apprehension about the procedure to develop any surgical or systemic complication; lack of skill for practical demonstration or knowledge regarding its efficacy. The meta-analysis of various techniques of the Raktamokshana, is primarily planned to study their effectiveness \& safety for managing multiple disorders. On an extensive review of the literature regarding this topic, 16 studies are conducted with 469 participants at different places or states from India. A narrative synthesis of all included studies \& their critical analysis was demonstrated concisely using tables. It was found that only two modes of Raktamokshana, i.e., Siravedha \& Jaoukavacharana, which are widely used in practice for different skin and musculoskeletal disorders, while only two trials study the modified Shringa method. No clinical study was carried out to demonstrate the effect of other methods of Raktamokshana or modifications in various clinical entities. The efficacy of three modes of Raktamokshana, i.e., Siravedha, Jalouka \& Shringa, can be justified based on the basic principles of Ayurveda \& physiological actions. This study demands to conduct scientific multicentric research studies with a large sample size in the future to embark on these conclusions \& to enhance their acceptance globally.
\end{abstract}

Key Words: Ayurveda; Raktamokshana; unawareness, Sirvedha, Jaoukavacharna, leech therapy.

\section{Introduction}

Raktamokshana is one of the essential procedures among five Penta- bio purificatory procedures as per Sushruta School. It is the important non-pharmacological intervention through which vitiated Rakta Dosha, along with Pitta, is eliminated through the body by using different techniques such as Sira vedha, Jaoukavacharna, Shringa, or Prachhana. Though it seems to be invasive, due to miraculous results, it is highly expected to adopt in complex clinical conditions where there occurs no relief with the use of specific Doshahara Chikitsa. It is considered as the half treatment in surgical diseases, according to Sushruta (1).

However, there are relatively limited recommendations or use of Raktamokshana in clinical practices of Panchakarma that may occur due to fear associated with the procedure, lack of skilfulness,

\section{* Corresponding Author:}

\section{Gaurav Sawarkar}

Associate Professor, Department of Rachana Shareer, Mahatma Gandhi Ayurved College Hospital and Research Centre, Salod (H), Datta Meghe Institute of Medical Sciences (Deemed to be University), Wardha, Maharashtra, India.

Email Id: drsawarkar.gaurav@gmail.com unawareness about the efficacy of Raktamokshana in various diseases. This review study is specially planned to compile the utility of various modes of Raktamokshana based on Ayurvedic and contemporary parameters with its detailed procedure. A total of 16 studies (Including clinical trial \& observational study) conducted on various musculoskeletal \& skin diseases treated with Raktamokshana are being evaluated in this paper.

\section{Aims}

The prime aim of this article is to compile the utility of Raktamokshana in various disorders on scientific \& clinical background.

\section{Objectives}

To review the application of various modes of Raktamokshana in different local as well as systemic disorders.

\section{Materials and Methods}

All information regarding above said aim \& objectives have complied from previous research studies, i.e., Ayurvedic Randomized \& non-randomized control trials \& observational studies on Raktamokshana within the duration year 1999 to April 2020 those conducted at different centers \& published 
on various peer-reviewed Journals, \& available on Pubmed, Google scholars, etc. from the year 1999-2020. Ayurvedic review articles on Raktamokshana, Case study, or case series showing the efficacy of Raktmokshana, modern articles on bloodletting therapy were excluded from the study.

References of key articles were hand-searched using the keywords such as "Raktamokshana," "Siravedha", "Prachhana", "Jaoukavacharana", "Ghati Yantra", "Shrungavacharana". Only publications having English language were eligible for inclusion. Both the screening of "title and abstract" and "full text" of the retrieved articles was conducted independently by two reviewers, and a third reviewer resolved any disagreement.

These selected studies were assessed for Inclusion \&Exclusion criteria for patient recruited in the studies, type of clinical conditions, type of methodology (whether study conducted with single group/ comparative groups/placebo-controlled or open /single or double-blind, etc.), type of Poorvakarma \& Paschata Karma adopted, different techniques used for Raktamokshana, various instruments or modification in the traditional instrument, the quantity of blood evacuated during one sitting, frequency of the Raktamokshana to get expected therapeutic outcome, nature of complications if arise, etc.

\section{Observations and Results}

A total of 44 articles were retrieved after searching the selected database, i.e., PubMed, Google scholars, Medknow, Web of Science, \& Shodhaganga using a comprehensive search strategy. On extensive review of literature from the above sources, due to duplication, 14 articles were removed. Among the rest of 30 items sorted based on screening as per title \& abstract, six papers were omitted as not related to the aim of the study \& objectives. Full text 24 articles were identified, but among them, 08 were withdrawn as those were not related to methodology. These 08 articles were excluded due to the following reasons: 03 articles were a literature review, 05 were case reports. The detailed description of the selection process of the included articles has been provided in Fig. 1 using the Prisma flow diagram.

Afterward, A systematic review synthesizing information from 16 studies (interventional \& observational) were enrolled in this study. Among these 16 studies, there are 12 R.C.T., 03 non-randomized controlled clinical trials \& 01 observational study. A total of 469 patients underwent various modes of Raktatmokshana in these trials. Among these 16 studies, six studies were carried out at I.P.G.T. \& R.A. Hospital, G.A.U., Jamnagar, ten studies at different study centers throughout India [01 at B.H.U. Jamnagar, 02 at Tirupati, 03 at Bangalore; 01 study conducted each at Nanded \& Mumbai, (Maharashtra), Paprola (Himachal Pradesh), \& Jaipur (Gujarat)]. Details of clinical studies conducted over hypertensive patients are as follows:

\section{Joshi F.et al. $2019(2)$}

It is an open-label prospective comparative clinical study conducted on 32 patients of either sex suffering from Kati Sandhigata Vata (lumbar Spondylosis) from the age group of 40-70 years by dividing them into two groups by computer-generated simple random sampling method ( $\mathrm{n}=16$ each group). The group A\& B were treated with Agnikarma with Panchadhatu Shalaka \& Raktamokshana with modified Shringa Yantra, respectively. The total duration of treatment was 25 \& 21days for groups A \& B, respectively. Simultaneously, one placebo capsule (500mg with wheat flour) twice a day was also prescribed after a meal with lukewarm water in both the groups.

After completing the treatment, significant reductions were observed in low backache, stiffness, numbness, and painful movements in both groups. The researcher concluded that Agnikarma was found more effective in relieving pain $(P<0.001)$ and numbness in the lower back. In comparison, Raktamokshana was found better in reducing pain $(P<0.001)$ and stiffness of the lower back $(P<0.005)$. Raktamokshana was found highly significant $(P<0.001)$ in improving forward flexion of lumbar joint, VAS, S.L.R., Lasegue's sign, ODI scale and Schober's test measurement, improvement in lumbar joint extension. There was $65.78 \%, 77.78 \%, 54.54 \%, 68.96 \%, 53 \%, 54.54 \%$ relief in Katishoola, Katisuptata and Akunchana, Prasarana Pravritti, Savedana, forward flexion of lumbar joint, measurement of Schober's test, straight leg raise test respectively due to Agnikarma which was better than Raktamokshana.

Whereas $90 \%, 50 \%, 55.55 \%$ \& $75 \%$ the improvement was observed in an extension of lumbar joints VAS, Lasegue's sign testing, and ODI scale due to Raktamokshana, which was comparatively better improvement than Agnikarma. The treatment modalities found similar improvement, i.e. (50\%) in lateral flexion of lumbar joints. No significant improvement or difference was observed in radiological findings in either group.

\section{P. N. Shilpa et al..2018 (3)}

An observational study was done over 40 Patients having Visarpa (Herpes Zoster) with the intervention of Jaoukavacharana done on the 1st day and then continued for every alternate day for 15 days with following its standard operating procedure After treatment, $100 \%, 100 \%, 92.5 \%, 95 \%$ recovery was observed in Sphota-Raga, Daha, Kandu induced by Visarpa. The researcher concluded that Jaoukavacharana has a significant role in achieving symptomatic relief in Pain. It also aids the faster healing of lesions \& Post Herpetic neuralgia that can be prevented through its early intervention.

\section{Jaiswal R.Reena. 2018 (4)}

It is a Single-blind comparative clinical study done with 40 patients having foot ulcers with either sex between the age group 17- 70 years divided into four groups ( $\mathrm{n}=10$ in each). The Group A was advised for 
Jaoukavacharana preceded by the Poorvakarma with Abhyanga \& Nadi Sweda for seven days \& followed by the application of Trishothadi Lepam externally. Group B was prescribed for Jaoukavacharanaonly. Group C underwent for Siravyadhana from the surrounding area of Ulcer (4 Anguli from the Ulcer) with Poorvakarma, i.e., Abhyanga \& Nadi Sweda, for seven days followed by Lepa Prayoga. Group D was undergone for Siravyadhana only. In this study, the process of Jaoukavacharana was found more effective for relieving vascular stasis, reducing venous congestion, and beginning of revascularization and other wound healing process than the Siravedha.

\section{Foram Joshi et. al. 2017 (5)}

Sixteen diagnosed cases having lumbar Spondylosis with sign and symptoms, i.e., Shula, Katistambha, Akunchana Prasarane Pravrutti Savedna \& Age group between 40-70 years were undergone for intervention with total four sittings of Raktamokshana with modified Shringa Yantra at the painful or tender area of the lumbar spine at the interval of 15 days preceded by Snigdha and Pichchhila Anna Pana Sevana. This Raktamokshana was followed by the Prachhna Karma (15-20 pricks) done with disposable needle no.24. over skin below the cups. Simultaneously Placebo capsules were prescribed $(500 \mathrm{mg}$ each) twice daily with lukewarm water after the meal throughout 60 days.

There was significant relief, i.e., 54\%, $93.5 \%$, $60 \%$ \& $81.25 \%$ in Kati Shula, Kati Stambha, Kati Suptata \& restricted joint movements respectively due to Raktamokshana. There was $61.5 \%, 50 \%, 90 \%, 50 \%$, $47.5 \%, 55.5 \%, 75 \%, 47.22 \%, 54 \%$ improvement was found in forward flexion of lumbosacral joint, lateral flexion, extension of lumbar joint. Visual analogs scale, straight leg raising, Laseague's test, ODI score, Schober's test, respectively. The researchers interpreted that Raktamokshana with Shringavacharana effectively manages Sandhigata Vata, having the origin of Margavarana Janya Samprapti.

\section{Kumar Vipin et. al. 2016 (6)}

This study was planned to study the efficacy of leech application over 17 patients with Pidaka (papules) over the face having Medogarbhatva, Ruja, Daha, Srava, Toda \&, Kandu. Two patients were dropped out of this study. There was observed statistically extremely significant results i.e., $68.91 \%, 77.77 \%$ \& $55.96 \%$ (for $\mathrm{p}$ values $<0.001$ ) in tenderness, Itching \& burning sensation respectively after leech application. However, it was statistically insignificant in symptoms such as discharge, Vranavastu, Medogarbhta for $\mathrm{p}$ $>0.05$. Statistically extremely significant results i.e., $72.20 \%, 82.11 \%, 72.42 \%, 81.79 \% \& 84.21 \%$ (for $\mathrm{p}$ value $\mathrm{v}<0.001$ ) were noted in number of Pidaka, its size, extent of lesion, hardness \& swelling, respectively. Jaoukavacharanaalone is very significantly effective in relieving the associated complaints like Kandu, Daha, and Vedana due to eliminating vitiated Rakta that indirectly corrects Pitta Dosha's results into the Srotoshodhana effect \& improvement in the local blood circulation by secretion of the various bioactive substances released by Jalauka.

\section{Manorma et.al. 2015 (7)}

The randomized, open, prospective clinical trial was conducted with a single group with the recruitment of patients having features of Gridhrasi (Sciatica) \& either sex between the age group 25-60 years. The Siravedha with sterile disposable syringe and needle from the Great Saphenous vein (Within the range of 2.5 $-5 \mathrm{~cm}$ area, in front and proximal to medial malleolus) of the affected side above the ankle was done that was preceded by the Local Snehana with Murchhit Til Taila 7 for 15 minutes and local Swedana with Patta Swedana for 5-7 minutes. It was performed at an interval of 10days (30ml in each sitting). After the third sitting of Siravedha, aggregate percentage relief was observed in Pain. Radiation of Pain, Stiffness, Pricking Sensations, Visual Analogue Scale (VAS), Verbal Descriptive Scale - V.D.S.), as well as Objective criteria (Passive straight leg raising test and Fajersztajn's test), was $35.11 \%$. Raktamokshana karma has an influential role in the management of Gridhrasi.

\section{Sonawane A. et. al.2014 (8)}

It is the clinical study conducted to assess the efficacy of Raktamokshana with the Modified Shringa method over ten patients having typical symptoms of calcaneus spur $\&$ of either sex between age 18 years to 70 years. Raktamokshana (approximately $10 \mathrm{cc}$ bloodletting) with a specially designed syringing instrument based on the principle of Shringa was performed preceded by Pracchan Karma over on the marked region followed by appropriate Paschata Karma. The intervention was performed at the interval of weekly once for four weeks.

There was observed complete relief in symptoms, e.g., Pain (intensity \& occurrence) with tenderness in calcaneus spur after third follow up due to this modified method of Raktamokshana.

\section{Pratap Shankar K.M. et. al. 2014 (9)}

It is an open-labeled clinical trial conducted over 27 patients having Vicharchika (Eczema) with the intervention of Jaloukvacharana with a minimum of four sittings at the interval of 7 days. After a successful intervention, there was a significant reduction in all symptoms of Eczema. There was remarkable reduction 54.45\% $(P<0.01), 55 \%(P<0.01)$ in Eczema Area and Severity Index (EASI) score, Scoring of Atopic Dermatitis (SCORAD) Index respectively. Moreover, the Dermatology Life Quality Index (D.L.Q.I.) was also improved by $62.36 \%(P<0.01)$. The researchers concluded that Jaoukavacharana is significantly effective \& safe in the management of Eczema.

\section{Kumar JV. et. al. 2014 (10)}

In this open randomized parallel trial, 30 patients with a known case of Gridhrasi \& between age group 25 and 65 years were divided into two groups, i.e., group A $(\mathrm{n}=19)$ and Group $\mathrm{S}(\mathrm{n}=11)$. Agnikarma with Panchadhatu Shalaka at lumbosacral spine and 
Achilles tendon \& Siravedha with disposable scalp vein no. 20 was done at the site of four Angula below Janu Sandhi (Knee joint) for groups A \& B respectively at seven days interval for four times. During Siravedha, a maximum of 30-60 $\mathrm{ml}$ of blood was removed \& it was decided according to condition and severity of the disease. Placebo starch capsules were given to all patients. No, significant changes were observed in radiological findings, i.e., X-ray of the lumbosacral spine in both groups. A total of 8 patients were dropped out of the study.

There were highly significant results i.e., $64.91 \%, 75.42 \%, 65.38 \%, 42.85 \%, 50 \%, 66.68 \%$ \& $66.09 \%, 75.02 \%, 100 \%, 75.02 \%$ were observed in Ruja, Stambha, Suptata, Spandana, Tandra, Gaurava \& Sakthinikshepanigraha, improvement in muscle power of hip flexion (ankle dorsiflexion \& great toe extension respectively due to Agnikarma with insignificant changes in lab investigations.

In Group S, i.e., Siravedha, highly significant results were seen in Ruka (33.32\%), Stambha (45.82\%), Suptata (58.62\%), Gaurav (57.15\%), and Sakthinikshepanigraha (46.14\%), but no significant improvement was observed in Spandana, Tandra \& muscle power. In lab investigations, there was a substantial decrease in only $\mathrm{Hb} \%$ after Siravedha (4.67\%). On comparing two groups, Agnikarma was found more effective than Siravedha in Ruka, Stambha, and S.L.R. Agnikarma gives a better effect in relieving symptoms of Gridhrasi than Siravedha.

\section{Vaneet Kumar et. al. 2014 (11)}

It is an open randomized parallel-group trial conducted over a total of 30 patients with Gridhrasi by dividing them randomly into two groups. Among them, one group $(\mathrm{n}=19)$ was treated by Bindu type of Agnikarma with Panchadhatu Shalaka (at lumbosacral spine and Achilles tendon region (total 5-30 Bindu Dahan at the lumbosacral area and 5-15 Bindu Dahan at ankle region of Achilles tendon) and another group $(\mathrm{n}=11)$ underwent for Siravedha with the help of disposable scalp vein no. 20 at the site of four Angulas below Janu Sandhi (Knee joint). Both interventions were done at an interval of 7 days (total of four sittings). An approximate 30-60 ml bloodletting was done per sitting, or it was decided according to the condition and severity of the disease. The Placebo starch capsule was also simultaneously prescribed to each patient.

A total of 8 patients were dropped out of the study. There was found a significant reduction in symptoms of Gridhasi in both groups. There was $68.42 \%$ \& $21.05 \%$ of patients had marked improvement and complete relief after Agnikarma, while $72.73 \%$ \& $27.27 \%$ of patients had moderate improvement \& marked improvement due to Siravedha. The researchers interfered that Agnikarma gives a better effect than Siravedha in the management of Gridhrasi for its Ruka, Stambha, and improvement in S.L.R. The researchers inferred that Siravedha is useful in patients when Avarana Janya Samprapti of Gridhrasi in Vata Kaphaja Gridhrasi.
Umale N. et.al. 2013 (12)

It is the clinical study done over ten patients having classical signs and symptoms of Gridharasi with the intervention of Siravedha (average $83 \mathrm{ml}$ bloodletting) at Antara Kandara Gulpha preceded by the appropriate Deepana with Ajamodadi Choorna (3gm B.D. with warm water), Sasneha Tila Yavagu, Sarvanga Abhyanga with Tila Taila and Bashpa Sweda for three days. Among ten patients, four patients got complete relief, while $8 \& 1$ patients got marked and moderate relief, respectively. There was found a reduction in the mean score of Pain in Gridhrasi from 4 to 0.7 after Siravedha \& the $82.5 \%$ relief in both tenderness along the course of sciatica nerve \& S.L.R. test.

\section{Athreya, P., P. et al. 2013 (13)}

An open, non-randomized study was conducted over patients with a confirmed diagnosis of Osteoarthritis, tendinitis, bursitis in which two leeches were applied twice at the interval of 1 day at painful peri-articular sites on the affected area of the knee joint. S.O.P. for the preservation of Jalouka is very well narrated in this article in a detailed manner. Follow up was taken on the 15 th day $\&$ after two months.

In the follow-up period, it was found that there was rapid \& significant relief after leech application in clinical features \& signs, e.g., Pain, Swelling, Stiffness, restriction of movement, A.R.A. Joint Count, R.A. Index of Pain associated with conditions with its sustainable relief even after two months of therapy. This study proved the anti-inflammatory effect of Jaoukavacharana.

\section{Raval H. et. al. 2012 (14)}

Twenty-nine patients with classical signs and symptoms of Vicharchika (Eczema) were randomly divided into the two groups, i.e., A group $(n=14)$ with Jaoukavacharanaand group B $(\mathrm{n}=15)$ with Siravedhana with Syringe method at the median cubital vein with average blood evacuation, $63.75 \mathrm{ml}$. Leech application was carried out in four consecutive weeks (weekly once while two sittings of Siravedhana Karma on the affected part of the body after local Abhyanga and Swedana (on every 15 days). $1 \& 2$ patients were dropped out from group A \& B, respectively.

Jaoukavacharanaprovided statistically high significant results $(\mathrm{P}<0.001)$ in the symptoms of

Vicharchika, like Kandu, Pidika, Raktima, and Daha. Therefore, researchers concluded that Jaoukavacharanahas better efficacy than Siravedha to manage Vicharchika.

\section{Rai. P. K. et. al. 2011 (15)}

It is a single group study conducted over 32 patients having Osteoarthritis of the knee (having idiopathic origin) with Knee pain, morning stiffness (lasting 30 minutes or less), crepitus on motion, and findings of osteophytes on radiographs. Jaoukavacharana, preceded by local Snehana \& Swedana, was applied once in a week for six weeks. Before the leech application, the skin was pricked by a 
sharp and sterile needle after cleaning the body part. After Samyak Jaoukavacharana, the process was followed by appropriate wound care \& Paschata Karma of Jalouka. After this intervention, significant improvement was found in Pain, stiffness, and tenderness (for $\mathrm{P}$ value $<0.001$ ), and the quality of life of the patient was also improved remarkably. However, there were occurred no changes in radiographical findings of the patients due to this intervention.

\section{Manoj L. Sonaje et al. .2011 (16)}

It is the randomized, open comparative study done between group A $(\mathrm{N}=32)$ \& group $\mathrm{B}(\mathrm{N}=30)$ in patients with classical signs and symptoms of Vicharchika \& between the ages group 10- 70 years. The group A was undergone for Local oil Massage) and Nadi Swedana, followed by Jaoukavacharana with bloodletting with the removal of an average $28 \mathrm{ml}$ blood. While group B was treated with the modified method of bloodletting, i.e., optic fiber tube attached with a vacuum pump and pressure regulator with the removal of average $27 \mathrm{ml}$ blood that preceded by Local oil Massage), Nadi Swedana \& then small 25 incisions with 11 no surgical blade at or near the lesion. Both interventions were done weekly once for four consecutive weeks. Significant results have occurred in both groups. However, significant results in Kandu, Vaivarnyata, Raji, Rukshata, Size of patches, Pidaka were noted in group A due to Jaoukavacharanafor pvalue $<0.001$. Moreover, no notorious or significant remarkable changes were observed in any hematological and biochemical parameters. Both methods of Raktamokshana, i.e., Jaoukavacharanaand Shringavacharana, are found effective in the management of Vicharchika.

\section{Sambhaji DT et al. 2010 (17)}

Sixty patients with classical signs \& symptoms of Gridhrasi were included in this study by dividing them into two groups ( $\mathrm{n}=30$ each). The trial group was treated with Siravyadha with scalp vein No-20 \& maximum $100 \mathrm{ml}$. blood was evacuated from the calf region of the affected leg at 4 Angula (finger) below the Janu Sandhi at the interval of weekly once. The control group was treated with local Abhyanga followed by the Nadi Swedana two times, i.e., daily for half an hour for 15 consecutive days. The trial group was found more effective than the control group, especially in reducing symptoms, e.g., pain (50\%), tingling sensation $(73.90 \%) \&$ loss of sensation $50 \%$ \& gross improvement in S.L.R. The researchers quoted that the Raktamokshana by Siravyadha is more effective than local Snehana\& Swedana to manage the signs \& symptoms of Gridhasi. He also commented that the patients with the Gridhrasi having Anubandha of Kapha, Pitta, or Rakta as a Dushya were received complete relief after Siravedha.

A summary description of the essential characteristics of the 16 included studies based on the different heads are as follows:

\section{Type of randomization \& methodology}

The type of methodology \& method of randomization (for R.C.T. only) of all included studies is mentioned in table no. 1 \& 2. Among 12 R.C.T., 01 R.C.T. has a single-blind controlled study design (4). The rest of the 11 were open randomized studies. Only two studies mentioned the specific type of randomization, i.e., Computer-generated random numbers (7) \& coding method (2). Simultaneously the rest of the seven trials have used a Simple Random sampling technique for randomization. All trials are single centric trials $\&$ there was no any multi-centric or double-blind study.

\section{Sample size}

The sample size of the studies was found to be varied based on the study design adapted. An observed study with a minimum sample size of $04 \quad \& \quad 62$ was the maximum sample size.

\section{Inclusion-Exclusion criteria \\ Inclusion (Indications \& age group selected)}

Total 16 studies were conducted to assess the clinical efficacy of Raktamokshana in different clinical conditions such as five works in Gridhasi; 1 work each in Lumber spondylosis, calcaneus spur, Foot ulcer, Visarpa, Pidaka \& clinical entities with acute Pain such as tendinitis-bursitis; 3 studies in Vicharchika (Eczema) and two works in Sandhigata Vata (Osteoarthritis Knee). Out of these, Siravedha is showed effective treatment in the clinical condition such as Lumber spondylosis \& Gridhasi. In comparison, Jalokavacharana is found effective in treating the skin conditions having local pathologies such as Vicharchika, Visarpa (Herpes), Pidaka \& even Musculoskeletal conditions such as Osteoarthritis, bursitis \& tendinitis. The two studies were conducted with a modified form of Shringa in patients with lumbar Spondylosis \& calcaneus spur.

Ideally, Raktamokshana is prescribed in patients with age group between $18-70$ years (18). However, an overview of this studies reflects that there is little bit variation regarding the age limit of the patients for different modes of Raktamokshana, e.g., for Shringa application, maximum patients were between 40-70 years while 17-70 years age group was primarily preferred were conducted to assess the clinical efficacy of Raktamokshana. For trials on Siravedha, age group 25-70 years were selected.

\section{Exclusions}

The patients with some specific physiological \& pathological contraindications described in these trials for Raktamokshana are tabulated in table no.3.

\section{Type of intervention (Different techniques used for Raktamokshana)}

Out of these 16 trials, maximum studies are carried out with Siravedha (8 studies), followed by Jalouka (7 studies). Minimum, i.e., only two studies, are carried out with Shringa with a modified method. There is no any single study conducted over Ghati 
Yantra or Prachhana. The number of studies with these different modes of bloodletting is depicted in table no. 4.

\section{Specific Poorvakarma adopted for Raktamokshana}

In these studies, Poorvakarma of different modes Raktamokshana includes assessing the indications \& contraindications of Raktamokshana, crosschecking the suitability of the patient, selection of the appropriate method of procedure, various Laboratory Investigations, selection of pre-procedure (Dipana-Pachana Abhyntar or Bahya Snehana, Local Swedana), preparation of the body part \& patient, diet planning, etc.

\section{Laboratory Investigations}

In this metaanalysis, laboratory investigations preferred before Raktamokshana are concise in tables no. $5 \& 6$. For Siravedha, only three studies have done routine investigations such as C.B.C., BT-CT before Siravedha $(4,12,14)$. Only one study has done E.S.R. (14) in Vicharchika as there is an inflammatory process aggravated. On the other hand, urine examination (microscopic \& routine) was done before Siravedha by Raval Hiren N. et al. .2012 (14) \& Jaiswal R.Reena $.2018(4)$.

Among the seven studies conducted on the Jaouka method, C.B.C. was advised by six trials except the trial done by K.M. Pratap Shankar et al. .2014 (9). B.T. \& C.T. were reported by only three trials $(4,14,15)$. Six trials mostly recommend C.B.C. \& R.B.S.

Among the four studies conducted on the Shringa method, only one study done by Manoj L. Sonaje et al. .2011 (16) have done C.B.C., R.B.S., E.S.R., Lipid profile, RFT \& Urine examination before its application.

\section{Dipana-Pachana}

The Poorvakarma of Raktamokshana is not specifically elaborated in our Ayurveda in the context of Dipana -Pachana or Abhyantar Snehana. However, local Snehana \& Swedana are recommended to enhance its effect in the form of Samyaka Yoga.

The Dipana Pachana with Ajmaodadi Choorna carried in the patients having Gridhasi for consecutive 3-5 days before Siravedha was noted in the study done by Umale et al. 2013 (12). In the rest of the 15 trials, there is no such type of Dipana Pachana used.

\section{Abhynatar Snehana}

There was observed a single reference showing the prescription of Sanseha Yavagu (a type of Sneha Pravicharana) for three days before Siravedha (12).

\section{Bahya Snehana}

In 8 trials conducted on Siravedha, Bahya Snehana was performed by four trials only. Til Taila or Moorchita Til Taila was advised for Bahya Snehana. Throughout these trials, it is observed that the duration of local Snehana varies from 3 days to 7 days for a maximum interval of 15 minutes. Bahya Snehana was preferred before leech application only by four studies
$(4,14,15,16)$. No specific drugs for local Snehana were mentioned in these trials. At the same time, Local Snehana used for before the Shringa application is quoted by the single study conducted by the Manoj L. Sonaje et al., .2011 (16).

\section{Local Swedana}

Local Swedana was prescribed before Siravedha by the four studies for a maximum of up to 7 days $(4,7,11,14,17)$. In comparison, the use of local Swedana prior to the Shringa application is quoted by the single study conducted by the Manoj L. Sonaje et al., .2011 (16).

Among seven studies on Jalukavacharana, local Swedana was done before leech application by four studies $(9,14,15)$. Preferably lukewarm water was used for that purpose (9). On the other hand, Nadi Swedana or Patta Swedana was utilized for this purpose by the study conducted by Sambhaji DT et al. 2010 \& Manorma Et Al.: $2015(7,17)$.

\section{Preparation of the body part prior to Raktamokshana}

On the day of leech application, preparation of the part was done with rubbing of the skin with the help of either sterilized cotton bandage pad or thick thread of jute (14) or Cleaning with the lesions of the patient took place with lukewarm water (3) or with normal saline (13). Before applying leech, the part should be pricked with a sharp and sterile needle as per Athreya, P. et al. 2013 (13).

Before applying Modified Shringa, the part should be cleaned with an antiseptic solution (8) or painted with a povidone-iodine solution followed by drying with a gauze piece (5). Afterward, the Pracchan Karma in the form of multiple superficial skin incisions (8) or small 25 incisions having approximate $1 \mathrm{~mm}$ depth was given at or near the lesion (16).

\section{Preparation of Leech (Purification of Jaluoka)}

In the 07 studies of Jaoukavacharana, purification of Jaluoka was done with water mixed with turmeric powder $(3,9,13,14,15)$ by keeping them maximum for 45 minutes, followed by in fresh water (14).

\section{Various instruments used for Raktamokshana}

For Siravedha, there is observed a variation in the use of instruments for venesection such as syringe method $(12,14)$, disposable scalp vein set no.20 $(4,11,17)$, sterile no.24 gauze hypodermic needle (7) was primarily used. The rest of the two studies have not mentioned the type of instruments used $(5,6)$. The conventional procedure of Siravyadha Kutharika Shastra was replaced by utilizing disposable scalp vein sets with 20 number, which is easily available, and there are minimum chances of sepsis (10).

\section{Site of Raktamokshana in different clinical conditions}

On review of the above trial, the site of Raktamokshana is decided based on the type of its 
mode used, type of pathology (local or systemic) \& textual references of the specific site of Raktamoshana in specific clinical conditions quoted in our Ayurvedic treatise.

Among all studies conducted on the Siravedha in Gridhasi, Siravedha is carried out at different sites such as lumbosacral region $\&$ at the region of Achilles tendon (10); 4 Angula below Janu Sandhi Over calf region in affected limb $(11,17)$; area within the range of $25-50 \mathrm{~cm}$ in the front \& proximal part of medial malleolus in the great saphenous vein (7) or tender area of the lumbar spine (5). However, Siravedha was performed from the median cubital vein in Vicharchika (14).

On the other hand, the studies performed with local techniques of Raktmokshana, such as the Jalouka \& modified method of Shringa, prefers the lesions of skin disease or tender region of the body affected by the musculoskeletal disorders as a site of bloodletting.

\section{Quantity of blood evacuated during one sitting}

This meta-analysis shows that the quantity of evacuated blood through per sitting of Siravedha varies from $30 \mathrm{ml}-100 \mathrm{ml}$. Raval Hiren N. et al. 2012 quotes that the amount of blood in each sitting of Siravedha should be equal to one Anjali of that patient, i.e., $63.75 \mathrm{ml}$, which was also supported by Acharya Sushruta (14).

Various studies performed with Jalouka didn't show the quantity of blood let per sitting except for 28 $\mathrm{ml}$, mentioned by Manoj L. Sonaje et al. 2011 (16).

In the studies conducted with the modified Shringa method, the quantity of bloodletting varies from 10-27 $\mathrm{ml}(8,16)$. Foram Joshi et al. 2017 quoted that blood should be evacuated until the stoppage of bleeding while bloodletting with the modified Shringa method (5).

\section{Frequency of the Raktamokshana}

The minimum duration of the study was seven days (12) \& the interval of 7 days was kept between the two sittings of Jaoukavacharana or Siravedha. Depending upon the severity \& chronic nature of the disease, this interval \& sitting of bloodletting was planned to get the expected therapeutic outcome. For pathologies with acute illness such as Visarpa, sitting of Jalouka are scheduled on an alternate day \& 2-5 sitting are recommended to recover the disease altogether. In sub-chronic conditions like Vicharchika, a minimum of 4 sittings are planned at an interval of 7 days. On the other hand, in chronic ailments such as O.A., Tendinitis maximum of 6 sitting is planned.

\section{Paschata Karma of Raktamokshana (Postoperative care)}

The above 16 recruited studies include the assessment of the proper symptoms of the procedures, observations for complications if developed any, the wound care, maintenance of instruments used for Raktamokshana including emesis \& appropriate preservation of leech for further use, precautions in the form of dietary advice, behavioral restrictions as
Paschata Karma of Raktamokshana. It will be narrated one by one as follows:

\section{Assessment parameters \& outcome measure}

In all 16 studies, assessment parameters are kept as depending upon signs \& symptomology of the patient. The outcomes reported by the included studies comprised of results in Objective \&Subjective parameters of the disease conditions.

\section{Effect of Raktamokshana over hematological \& biochemical parameters}

The increase in the proportion of serum after bloodletting with leech application is noted by Vaneet Kumar et al. .2014 (11). In the Siravedha group, average Hemoglobin level fall occurred from 13.027 to $12.418 \mathrm{~g}$ $\%$ (reduction by $4.67 \%$ ) but did not have any adverse effects. The change in $\mathrm{Hb} \%$ after Siravedha can be attributed to direct letting out of R.B.C.s, thus affecting the level of $\mathrm{Hb}(11)$.

\section{Observations for complications}

A single study noted no complication or an adverse event. Though superficially, the various modes of Raktamokshana seem to be invasive, these are safe \& offer the maximum therapeutic benefits if we follow the proper S.O.P. of that procedure.

\section{Wound care}

Wound care after bloodletting is primarily planned to arrest bleeding \& to avoid sepsis in the wound. After the expected quantity of bloodletting by Jalouka, the detachment of leech should be done with Turmeric powder $(13,15)$ or sprinkling salt over them (14). Wound after leech application was cleaned with an antiseptic solution (14) or dressed with a gauze containing Haridra powder (3).

After Shring application, Haridra Churna dusting (2,5); application of Goghrita (8); dressing with antiseptic solution (8); application of Haridra Churna with Madhu (Honey) (5) is recommended over the site of bloodletting with Shringa for wound care.

The tight bandage was advised after Siravedha \& Jaoukavacharana to arrest bleeding at the Raktamokshana site in most of the studies. In comparison, the application of Haridra and Yasthimadhu powder was applied for the Vrana Sandhana(wound healing) and to avoid sepsis after Siravedha $(13,17)$.

\section{Maintenance of instruments/Jalouka used for Raktamokshana}

The study conducted with leech application includes the emesis of leech with their appropriate preservation for further use as an essential part of postprocedure care. Emesis of leech was done with turmeric water, followed by fresh water (3). S.O.P. for the preservation of Jalouka is extensively elaborated by Athreya, P., P. et al. 2013 in his published article (13). 


\section{Dietary advice}

An unwholesome diet was advised after Siravedha by Jaiswal R.Reena .2018[4]. Moreover, a light, palatable diet \& haematogenic food is suggested after Siravedha by Sambhiaji DT et al2010 (17) \& Manorma Et Al.: 2015 (7) respectively. No specific dietic or behavioral restrictions are advised after leech application by any study. The Foram Joshi et al. 2017 recommends the intake of honey and water after Raktmokshana with the Shring method (5). He further suggested avoiding Vatavriddhika Ahara and Vihara also after the procedure.

\section{Behavioral restrictions}

Bed rest was advised for at least half an hour after Siravedha by Sambhaji DT et al. 2010 (17). While the patient was advised to keep the foot end elevated, area dry, clean, avoid exertion, trauma after Siravedha by Jaiswal Reena 2018 (4) \& the patient should be asked to remain to be relaxed by Manorma Et Al.: 2015 (7). After the application of the Shringa method, the patient was advised to take rest and to avoid water contacts on the operated site for 24 hours (2) \& was restricted to apply any oil or cream over the area of bloodletting (5).

\section{Discussion}

A total of 16 trials carried out at different centers are screened and critically analyzed to verify the necessity and assess the role of Raktamokshana among various disorders such as Gridhrasi, Visarpa, foot ulcer, Yuvanapidaka, Vicharchika (Eczema), Eczema, idiopathic Osteoarthritis, tendinitis, bursitis, lumbar Spondylosis \& calcaneal spur. No adverse effects were reported in these trials after any type of bloodletting. A total of 469 subjects were recruited in these trials. Among these 469 patients, various modes of Raktamokshana were assessed in 370 subjects 117,174 \& 79 patients underwent for Siravedha, Jaoukavacharana \& modified Shring method, respectively). The patients between the age group, 1670 years, were recruited in these different studies, also quoted by Acharya Sharangadhara for Raktamokshana (18).

Six trials mostly recommend C.B.C. \& R.B.S. It may be justified as Raktamokshana is strictly contraindicated in Pandu \& Prameha (19). The use of Dipana-Pachana prescribed in the study conducted by the Umale et al. .2013 can be justified as Dipana Pachana plays a vital role to decrease the intensity of symptoms, e.g., Agnimandya, Aruchi \& Gauravata due to Kapha \& Ama Anubandha that commonly occurs in Vatakpahaja Gridhrasi (20). Therefore, Dipana Pachana should be added in the pre-procedure prescription of Siravedha based on the assessment of the Agni. However, Dipana is not expected before the adoption of local techniques of Raktmokshana.

No specific drugs or its quantity or duration is mentioned for Abhynatar Snehana before Raktamokshana throughout the Ayurvedic literature. Still, considering the nature of diseases (acute or chronic), state of Dosha involvement of predominance of Dosha \& type of constitution of the patient, use of the various aspect of Abhynatara Snehana should be taken into consideration. Considering the variation in the quantity of blood in different methods of Raktamokshana, it can be stated that the amount of blood evacuated should be decided based on the requirement of a grade of purification, pathology of the disease along with mental \& physical strength of the patient. The outcomes (results in Objective \& Subjective parameters) reported by the included studies conducted with various techniques of Raktamokshana with their probable mode of actions can be justified as follows:

\section{Mode of action of Siravedha}

Siravedha karma has a significant role in the management of Gridhrasi to relive its sign, symptoms, i.e., Ruka, Stambha, Suptata, Gaurav, and Sakthinikshepanigraha \& improvement in S.L.R. $(7,11)$. It reduces all these symptoms by relieving venous congestion, increasing venous drainage, and increasing oxygenated blood supply near the applied area. The role of the Siravedha is already highlighted by the Sushruta in the treatment principle of Gridhasi (1). Mostly it is highly effective in Gridhrasi with Anubandha of Kapha \& involvement of as a Dushya such as Pitta or Rakta as it induces the Anulomana of Vata by removing the Avarana of Pitta and Kapha Dosha $(10,17)$.

In Siravedha, the expulsion of morbid humor (vitiated Doshas) accumulated due to inflammatory reaction induces relief in Pain immediately due to its Vata Shamana effect, by masking the Sheet Guna of the Vata by the Ushna Guna of the Rakta as a result of increased blood circulation by Siravedha (17) Its analgesic effect may occur due to the reduction in intravascular volume \& pressure (21). Stambha \& Suptata in Gridhasi chiefly occurs due to Sheeta and Ruksha Guna of Vata Dosha (10) in which Raktamokshana is indicated by Sushruta $(22,23)$. It reduces numbness by reducing peripheral resistance. Hence, in superficial nerve involvement, Siravedha was found effective in relieving Suptata. Siravedha also reduces the Avarana of Rakta developed in Gridhasi.

\section{Mode of action of Jaouka}

Jalouka induces significant relief in Shoola developed by in Visarpa (immediate pain relief sustained for 7-8 hrs), i.e., Herpetic neuralgia, and helps heal its lesions fastly (3). It arrests the Paka(further suppuration) by expelling the Dushta Rakta \& Pitta. It prevents a secondary infection and facilitates the healing of lesions due to the antibiotic property of Hyaluronidase secreted by leech (3).

Jaoukavacharana is also effective in the healing of foot ulcers than Siravedha as it relieves vascular stasis, reduces venous congestion, and initiates the revascularization \& granulation tissue formation that ultimately turns into rapid wound healing. This healing may occur due to normalization and improvement in the capillary as well as collateral blood circulation. Its anti-inflammatory, analgesic, immuno- 
stimulation, and Immuno-modulator properties potentiate this effect (4).

Jaoukavacharana is also significantly effective in Yuvanapidaka by reducing Kandu, Daha, and Vedana in it. It can be justified as it induces the Srotoshodhana by eliminating vitiated Rakta \& Pitta Dosha \& improvement in local blood circulation due to various bioactive anti-inflammatory substances released by Jaouka (6).

Leech application reduces Eczema Area and Severity Index (E.A.S.I.) score, Scoring of Atopic Dermatitis (S.C.O.R.A.D.) The index in Vicharhcikā (Eczema) \& effective than Siravedha. It initiates the keratolysis resulting in a reduction in thickness of skin lesion of Eczema. It reduces the oozing in Eczema due to the antibiotic property of hyaluronidase secreted by the leech. Anti-inflammatory and antifungal property of eglins and bdellins secreted by the leech also enhance the anti-eczematous effect of therapy $(9,14)$. It decreases the itching in Vicharchika and Yuvanapidaka by inducing microcirculation and reducing inflammatory components like lymphocytes.

Moreover, Jaoukavacharana reduces the symptoms such as Pain, Swelling, morning Stiffness, Restriction of Movement, tenderness, A.R.A. Joint Count, R.A. Index of Pain in Osteoarthritis including idiopathic origin, tendinitis, bursitis $(13,15)$. Antiinflammatory, vasodilator, superoxide production, and poorly characterized anesthetics and analgesic compounds released by the leech penetrate the periarticular tissue and adjacent structures \& induce analgesic effect through antinociceptive effects and counter-irritation. It also reduces the inflammation in relative structures by inhibiting the chemicals such as adenosine, prostaglandin (P.G.) E1and PGF2 $\alpha$, leukotriene B4, and (8R-15S)-dihydroxyeicosa(5E-9,11,132)-tetraenoic acid (8R-15S-diHETE) which are responsible for Inflammation in such musculoskeletal disorders (13).

\section{Mode of action of Shringa}

Raktamokshana with Modified Shringa Yantra is effective in lumber spondylosis than the Agnikarma to relieve Pain (VAS) and stiffness of the lower back \& to improve in extension \& forward flexion of lumbar joints, Lasegue's sign, Schober's test measurement, and ODI scale (2). This method of bloodletting is also effective in managing Sandhigata Vata, having the origin of Margavarana Janya Samprapti (5) \& calcaneal spur by reliving its intensity \& frequency of Pain, tenderness (8). It reduces the Pain by removing Avarodha due to Vata \& Kapha in Sandhigata Vata. It also destroys Avarana of Kapha Dosha over Vyana Vayu and establishes Prakrita Rasa-Rakta Samvahana (normal blood circulation). It helps to develop proper blood flow and nutrition to the tissues \& structures nearby, which rejuvenates the joint structures and rehabilitates the joint movement (5). Application of modified Shringa Yantra in Dhatukshaya Janya Samprapti (pathology of tissue degeneration) removes Vata vitiated blood from localized circulatory pathways (micro-vascular structures) and resumes adequate fresh blood flow that results in normal joint function and reduces the symptoms. By removing nutrition to osteophytes, extra bony growth, abnormal bony tissues, it reanalyzes' the nutritional pathway to the lumbar joints. Jaoukavacharanaand Shringavacharana are both effective in the management of Vicharchika (16).

There are observed no changes in radiological findings after using any technique of Raktamokshana in lumbar spondylosis. Therefore, treatment duration \& frequency of Rakatamokshana should be increased to study \& observe the efficacy of various modes of Raktamokshana in radiological findings of musculoskeletal or rheumatological ailments such as Osteoarthritis or lumbar spondylosis (2).

\section{Conclusion}

The novel attempt is performed through this current metaanalysis to collate shreds of evidence regarding the efficacy \& safety of the Raktamokshana in various disorders. In some studies, intervention for a short duration with a small sample also demonstrated quick significant results over signs \& symptoms of the disease. However, strict monitoring of such a study is necessary for the future to embark on their conclusions.

It is also needed to undertake further studies over a large sample size with long duration to assess the sustainability of the effects of such interventions. Therefore, future studies should be planned with a rational approach given by these studies but by keeping in mind all these shortcomings of the previous studies.

\section{Acknowledgment}

I would like to offer sincere gratitude to Datta Meghe Institute of Medical Sciences (Deemed to be University), Wardha, Maharashtra

\section{The conflict of interest: nil}

\section{References}

1. Sushruta, Sushruta Samhita, Ayurved Tatva Sandipika, Dr. Ambikadata Shastri, Chaukhambha Sanskrit Sansthan, Varanasi, 2001, Sharir Sthan-8/23 page 67

2. Joshi F, Mahanta V, Dudhamal TS, Gupta SK. Effect of Agnikarma (therapeutic heat burns) and Raktamokshana (therapeutic bloodletting) in the management of Kati Sandhigata Vata (lumbar spondylosis). Ayu. 2019 Apr;40(2):79.

3. Shilpa P. N., Dr. T. D.2018 Ksheerasagar.Efficacy of Jaoukavacharanain visarpa w.s.r to herpes zoster - an observational study. World Journal of Pharmaceutical Research Volume 7, Issue 14, 800-813.

4. Jaiswal Reena. Comparative study on the effect of and along with on foot ulcers. J. Ind. Sys.Med. 2018;6(3):122-129

5. Foram Joshi, Mahanta V. D, Dudhamal T. S, Gupta S. K. 2017 Shringa Avacharana in the management of Sandhigata Vata WSR to Lumbar spondylosis.A Pilot Study. Ayurlog: National Journal of Research 
in Ayurved Science-2017 ;(5) (Ayur Kaushalya special issue) 53- 63

6. Kumar Vipin et al.: Efficacy Of Jalukavacharana In The Management Of Yuvanapidaka W.S.R. To Acne Vulgaris- A Pilot Study. International Ayurvedic Medical Journal \{online\} 2016 \{cited 2016 July\}

7. Manorma Et Al.: Effect Of Raktamokshana Karma In The Management Of Gridhrasi. IJAAR VOLUME II ISSUE I MAY-JUN 2015;p.39-46

8. Sonawane Abhinav Sangahvi Mahesh Dharne Vidya.2014effect Of Raktamokshana On Calcaneal Spur. IAMJ: Volume 2; Issue 1; Jan - Feb 2014

9. Shankar KP, Rao SD, Umar SN, Gopalakrishnaiah V. A clinical trial for evaluation of leech application in the management of Vicarcikā (Eczema). The ancient science of life. 2014 Apr;33(4):236.

10. Kumar JV, Dudhamal TS, Gupta SK, Mahanta V. A comparative clinical study of Siravedha and Agnikarma in management of Gridhrasi (sciatica). Ayu. 2014 Jul;35(3):270.

11. Vaneet Kumar, Tukaram S. Dudhamal, Sanjay Kumar Gupta, and Vyasadev Mahanta A comparative clinical study of Siravedha and Agnikarma in management of Gridhrasi (sciatica), Ayu. 2014 Jul-Sep; 35(3): 270-276

12. Umale Nandkishor1 R Kumari Shylaja Efficacy Of Siravedha In The Management Of Pain In Gridhrasi, IAMJ: Volume 1; Issue 6; Nov - Dec 2013, p.51-55

13. Athreya, P., P. Grampurohit, S. Jahagirdhar, and H.D. Tosikhane. 2013. "Effectiveness of Jalaukavacarana (Leech Therapy) in Acute Inflammatory Joint Disorders." Pacific Journal of Science and Technology. 14(2):391-396

14. Hiren N. Raval and A. B. ThakarRole of Raktamokshana by Jaoukavacharanaand Siravedhana in the management of Vicharchika (Eczema) Ayu. 2012 Jan-Mar; 33(1): 68-72.

15. Rai P. K, Ph.D., Singh A. K., Ph.D. Scholar, Singh O. P., Rai N. P., and Dwivedi A. K. Efficacy of leech therapy in the management of osteoarthritis (Sandhivata) Ayu. 2011 Apr-Jun; 32(2): 213-217.

16. Manoj L. Sonaje1, Dhiman K. S2, Bhuyan C3, Gupta S. K4, Dudhamal T. SComparative assessment of Jaoukavacharana (Leech Application) and Shringavacharana (Horn Application) in Vicharchika, International Journal of Ayurvedic Medicine, 2011, 2(4), 2

17. Sambhaji DT, Kumar GS, Bhuyan C. Clinical evaluation of Siravyadha in the Management of Gridhrasi. Indian Journal of Ancient Medicine and Yoga. 2010 Apr;3(2).

18. Murthy KR, translator. Sharangadhara Samhita by pandit sharangadhara with commentary of Adhamalla Dipika and Kashiram's Gudarthdeepika, Editor, Pandit Parashuram Shastri, Vidyasagara, Uttarkhanda, chapter, Verse, Chaukhamba orientalia, Varanasi: th $^{\text {th }}$ edition,2006, P.N.255

19. Sharma Priyavata, Editor, Sushruta Samhita of Sushruta, editor, Volume II,shareersthana, chapter 8, verse 3, Chaukhambha Viswabharati, Varanasi, Reprint 2005,p.n.167

20. Sawarkar P, Sawarkar G. Ayurvedic management of Gridhasi Sciatica. Joinsysmed. 2017 Apr 1;5 $: 119-25$.

21. Rathod KS, Siddiqui S, Sin B, Hogan J, Gupta S. Secondary prevention regimens and risk factors are not optimized in patients re-admitted with ACS. British Journal of Cardiology. 2012;19(4):167.

22. Acharya Trikamji. Editor, Sushrutasamhita of Sushruta with Dalhanacharya Nibandhasangraha commentary, Volume II, Chikitsa sthana, chapter4, verse 12, Chaukhamba orientalia, Varanasi,9 th edition,2007P.N.226

23. Mohan M, Sawarkar P. Ayurvedic management of Gridhrasi with special respect to sciatica: a case report. Journal of Indian System of Medicine. 2019 Apr 1;7(2):131.

Figures:

Fig. 1: PRISMA FLOW DIAGRAM
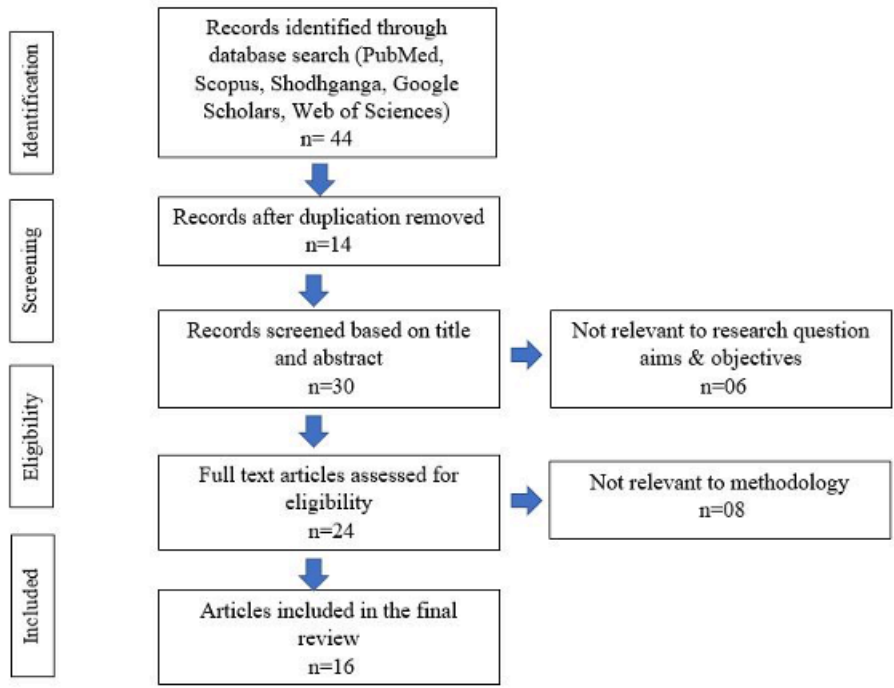
Tables:

\begin{tabular}{|c|c|c|}
\hline S.N. & Type of methodology of the study & Number of studies \\
\hline 1 & $\mathrm{RCT}$ & 12 \\
\hline 2 & Non -RCT & 3 \\
\hline 3 & Observational & 1 \\
\hline 4 & Studies with a single group & 9 \\
\hline 5 & Studies with comparative groups & 7 \\
\hline 6 & Study with Placebo $(2,11)$ & 2 \\
\hline 7 & Combination with Shamana Chikitsa (13) & 1 \\
\hline 8 & Open study & 12 \\
\hline 9 & Single-blind studies (4) & 1 \\
\hline
\end{tabular}

Table No. 2: Type of method of Randomization used for RCT

S.N. Type of method of Randomization

Number of studies

$1 \quad$ Coding method (7)

2 Computer-generated table method (2)

1

Table no.3: Patients excluded for Raktamokshana

\section{S.N. Pathological}

1 Any Hematological or bleeding disorders/Blood clotting disorders

2 Severe anemia $($ Hemoglobin $\%<07.00 \mathrm{mg} / \mathrm{dl})$

3 Allergic reaction to active substances of the leech such as hirudin, calin, Pregnancy

Physiological

The human with a weak constitution

Below the age of 14 yrs and above 60 yrs

hyaluronidase, e.g., line, collagenase, apyrase, destabilise, piyavit, etc.

4 Uncontrolled diabetes mellitus

5 Vatavydhi such as paralysis, Parkinson's disease

6 Malignancy

7 Patients having secondary infections

8 Heart diseases (ischemic heart disease, coronary artery disease, myocardial infarction)

9 Infective or immuno-compromised conditions such as tuberculosis, AIDS

10 Leprosy

11 Peripheral neuropathy

12 Hepatitis A, B

13 Use of Systemic antibiotics in the previous four weeks.

14 Patients on non-steroidal anti-inflammatory drugs

15 Serious Endocrine disorders

16 Renal failure

Table No. 4: Number of studies with a specific mode of intervention in specific clinical conditions

S.N. Type of mode of Raktamokshana Number used

of studies

1 Siravedha

8 Lumbar Spondylosis, Gridhasi, Foot ulcer

2 Jaoukavacharana

3 Shringa (Modified method)

7 Osteoarthritis, Bursitis, tendinitis, Pidaka, Vicharchika, Visarpa, Foot ulcer

2 Lumbar spondylosis, Calcaneous spur 
Gaurav Sawarkar et.al., Raktamokshana - A Systemic Review

Table no.5: Laboratory Investigations advised before Siravedha

\begin{tabular}{|c|c|c|c|c|c|c|c|c|c|}
\hline S.N. & $\begin{array}{l}\text { Type of Blood } \\
\text { Investigations }\end{array}$ & $\begin{array}{c}\text { Raval } \\
\text { Hiren N. } \\
\text { et al. } \\
.2012 \\
\text { (14) }\end{array}$ & $\begin{array}{c}\text { Kumar } \\
\text { JV.et } \\
\text { al.2014 } \\
\text { (10) }\end{array}$ & $\begin{array}{l}\text { Sambhaji } \\
\text { DT et al. } \\
2010(17)\end{array}$ & $\begin{array}{c}\text { Manorma } \\
\text { Et Al.: } \\
2015(7)\end{array}$ & $\begin{array}{c}\text { Umale } \\
N . \\
\text { et.al.201 } \\
3(12)\end{array}$ & $\begin{array}{l}\text { Jaiswal } \\
\text { R.Reena } \\
.2018(4)\end{array}$ & $\begin{array}{c}\text { Vaneet } \\
\text { Kumar } \\
\text { et al. } \\
2014 \\
\text { (11) }\end{array}$ & $\begin{array}{c}\text { Forma } \\
2017 \\
(5)\end{array}$ \\
\hline 1 & $\mathrm{CBC}$ & & - & - & - & & & - & - \\
\hline 2 & LFT & - & - & - & - & - & & - & - \\
\hline 3 & RBS & - & - & - & - & - & & - & - \\
\hline 4 & BT-CT & & - & - & - & & & - & - \\
\hline 5 & HIV & - & - & - & - & - & - & - & - \\
\hline 6 & ESR & & - & - & - & - & - & - & - \\
\hline 7 & Lipid profile & - & - & - & - & - & - & - & - \\
\hline 8 & RFT & & - & - & - & - & & - & - \\
\hline 9 & Urine & & - & - & - & - & & - & - \\
\hline
\end{tabular}

Table no.6: Laboratory Investigations advised before Jaoukavacharana

\begin{tabular}{|c|c|c|c|c|c|c|c|c|}
\hline S.N. & $\begin{array}{l}\text { Type of Blood } \\
\text { Investigations }\end{array}$ & $\begin{array}{l}\text { Rai. P.K. } \\
\text { et al. } \\
2011 \text { (15) }\end{array}$ & $\begin{array}{c}\text { Raval } \\
\text { Hiren } N . \\
\text { et al. } 2012 \\
\text { (14) }\end{array}$ & $\begin{array}{c}\text { K.M. } \\
\text { Pratap } \\
\text { Shankar et } \\
\text { al.2014 (9) }\end{array}$ & $\begin{array}{l}\text { Manoj L. } \\
\text { Sonaje et } \\
\text { al. .2011 } \\
\text { (16) }\end{array}$ & $\begin{array}{c}P . N . \\
\text { Shilpa et } \\
\text { al..2018 } \\
\text { (3) }\end{array}$ & $\begin{array}{c}\text { Athreya, } \\
\text { P., P. et al. } \\
2013 \text { (13) }\end{array}$ & $\begin{array}{l}\text { Jaiswal } \\
\text { R.Reena } \\
.2018(4)\end{array}$ \\
\hline 1 & CBC & & & - & & & & \\
\hline 2 & LFT & & - & - & - & - & & - \\
\hline 3 & RBS & & - & - & & & & \\
\hline 4 & BT-CT & & & - & - & - & - & \\
\hline 5 & HIV & & - & - & - & & - & - \\
\hline 6 & HBs AG & - & - & - & - & & - & - \\
\hline 7 & ESR & - & & - & & & - & - \\
\hline 8 & lipid profile & - & - & - & & - & - & \\
\hline 9 & RFT & - & - & - & - & - & & \\
\hline 10 & LFT & - & - & - & & - & - & - \\
\hline
\end{tabular}

